librarian. Further, our relationship with career development has been enhanced greatly through our mutual planning and interaction.

\section{Concluding remarks}

Ought we to recruit for our profession? We say yes, and with an enthusiastic recommendation that you try something similar to our initial attempt! (You will need a minimum budget of about \$300). The planning involved in a such venture is considerable, but the visibility and reward that accrue in the process are gratifying. In higher education we are in the business of opening the minds of our students. That "library and information science" exists will be revelatory to many. That it is a true academic discipline will be shocking to most. But the study and practice of librarianship in its growing dimensions will be pleasantly surprising to at least a few.

The author wishes to thank his colleague, Daniel J. Bowell, for his criticism and editorial assistance.

\title{
ACRL officers for 1984-85
}

\section{The official ACRL election results.}

$\mathrm{S}_{\mathrm{H}}$ J J RoGERS, university librarian at George Washington University (Washington, DC 20052), is the forty-seventh president of the Association of College and Research Libraries. During her one-year term of office, she will preside over the ACRL Board of Directors and the ACRL Executive Committee. She will chair the ACRL Conference Program Planning Committee for the 1985 ALA Annual Conference in Chicago and will plan ACRL's major program at the conference.

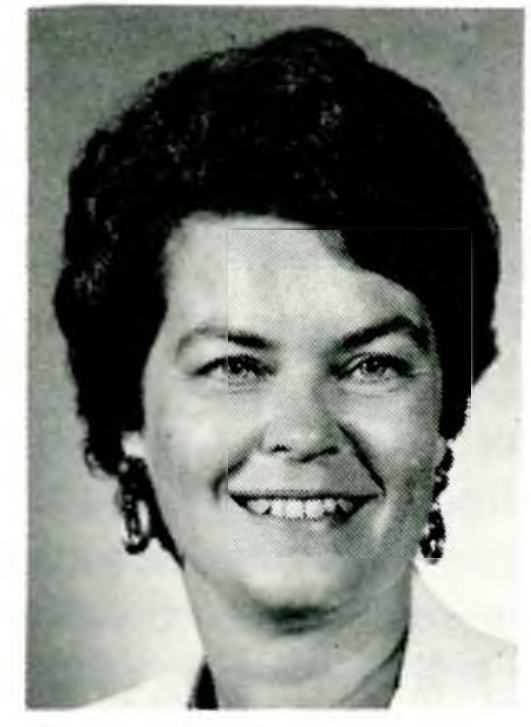

Sharon J. Rogers
As president of the di-

vision, Rogers will represent ACRL on the ALA Chicago Conference Program Committee. She will also represent ACRL and ALA in their relations with other organizations. Rogers has contributed to ACRL as a member of the ACRL Board of Directors, as chair of the Task Force on Academic Libraries and Higher Education, as chair of the Advisory Committee for the Bibliographic Instruction
Liaison Project, and as chair of the Bibliographic Instruction Section (1980-1981). Last year she served as chair of the Legislation Subcommittee of the ALA Status of Women in Librarianship Committee, and as a member of the OHIONET OnLine Reference Council.

Sharon Anne Hogan, director of the Troy Middleton Library, Louisiana State University (Baton Rouge, LA 70803), has been elected vicepresident/presidentelect of the Association of College and Research Libraries. The 1984 election results showed 1,240 votes for Hogan and 1,024 for Janice $T$. Koyama, head of Moffitt Undergraduate Library at the University of California, Berkeley.

As vice-president/ president-elect of ACRL, Hogan will serve on the ACRL Board of

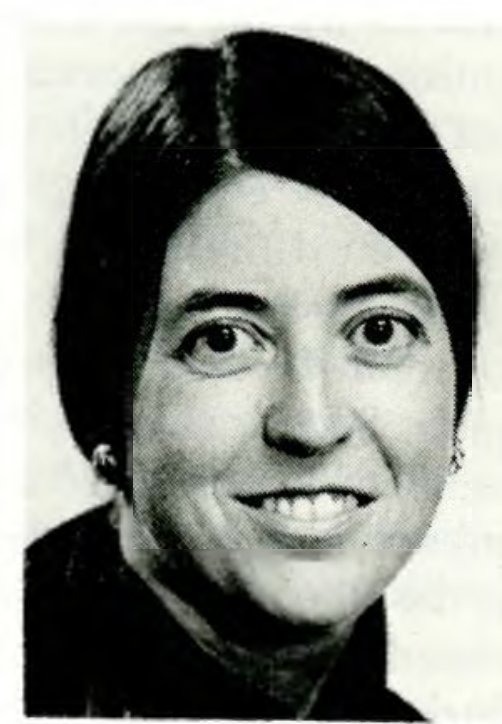

Sharon Hogan Directors and the ACRL

Executive Committee. She will chair the ACRL 
Conference Program Planning Committee for the 1986 Annual Conference in New York. She will represent ACRL on the ALA Appointments Committee, the ALA Planning and Budget Assembly, and the ALA Conference Program Planning Committee for the 1986 conference. At the end of the 1985 Annual Conference, she will become ACRL's forty-eighth president.

Hogan has been very active in ACRL and currently serves as chair of the Task Force on ACRL/ALA Relations and as a member of the ACRL Budget and Finance Committee (since 1980). In 1979-1980 she was chair of the Bibliographic Instruction Section. She is co-founder and co-editor of the periodical Research Strategies and co-author of Learning the Library: Concepts and Methods for Effective Bibliographic Instruction, published in 1982.

Hogan began her appointment at LSU on July 9 , coming from Temple University where she was acting director since 1983. From 1971 to 1982 she held several positions at the University of Michigan where she received her MLS in 1968.

The results of the ACRL elections follow. For each position, the elected candidate is listed first. The number of votes earned by each candidate is listed in parentheses.

\section{Directors-at-Large to the ACRL Board of Directors}

Director-at-Large (four-year term): EDWARD J. Jennerich, Academic Dean, Virginia Intermont College, Bristol, VA 24201-(1,215); Pamela L. Wonsek, Head of Branch and External Services, Mercy College Library, 555 Broadway, Dobbs Ferry, NY 10522 (862).

Director-at-Large (two-year term): JOAN I. Gotwals, Deputy Director of Libraries, University of Pennsylvania, Philadelphia, PA 19104 $(1,131)$; Kenneth G. Peterson, Dean of Library Affairs, Southern Illinois University, Carbondale, IL $62901(1,021)$.

Director-at-Large (four-year term): W. LEE Hisle, Director of Learning Resource Services, Austin Community College, P.O. Box 2285, Austin, TX 78768 (1,069); Rosemary Henderson, Director of Learning Resources, Coffeyville Community College, 11th and Willow, Coffeyville, KS 67337 (956).

\section{Anthropology and Sociology Section}

Vice-Chair/Chair-Elect: JEAN SHAw AdELman, Librarian, University Museum, University of Pennsylvania, Philadelphia, PA 19104 (56); Lynne M. Schmelz-Keil, Head of Public Services, John Cotton Dana Library, Rutgers-The State University, 185 University Avenue, Newark, NJ 07102 (19).

Member-at-Large (two-year term): Chris D. Ferguson, Social Sciences Bibliographer, Univer- sity of California Library, Irvine, CA 92713 (30); Ann L. Wood, Reference Librarian, Goodell Library, University of Massachusetts, Amherst, MA 01002 (28); Cheryl C. Kugler, 819 Neartop Drive, Nashville, TN 37205 (18).

\section{Art Section}

Vice-Chair/Chair-Elect: DARryl DEAN BARRETT, Art and Music Librarian, Minneapolis Public Library, 300 Nicollet Mall, Minneapolis, MN 55401 (64); James H. Carmin, Reference Librarian, Architecture and Allied Arts Library, University of Oregon, Eugene, OR 97403 (23).

\section{Asian and African Section}

Vice-Chair/Chair-Elect: Thomas H. LEE, Team Captain, East Asian Languages Cataloging Team, University of Wisconsin Memorial Library, 728 State St., Madison, WI 53706 (56); Margaret K. Wang, Serials Catalog Librarian, University of Delaware Library, Newark, DE 19711 (24).

Member-at-Large (three-year term): CECELIA L. Shores, Head of Acquisitions, Center for Research Libraries, 6050 S. Kenwood, Chicago, IL 60637 (44); Katharine K. Elsasser, Senior Subject Cataloging Specialist, Library of Congress, Washington, DC 20540 (34).

\section{Bibliographic Instruction Section}

Vice-Chair/Chair-Elect: MARY REICHEL, Head, Reference Department, Pullen Library, Georgia State University, 100 Decatur St., S.E., Atlanta, GA 30303 (329); Virginia Tiefel, Head, Undergraduate Libraries, Ohio State University, 1858 Neil Ave. Mall, Columbus, OH 43210 (325).

Secretary: BETSY BAKER, Bibliographic Instruction Services Librarian, Northwestern University Library, 1935 Sheridan Rd., Evanston, IL 60201 (399); Ellen Meltzer, Assistant to the Associate University Librarian for Public Service, 245 Doe Library, University of California, Berkeley, CA 94720 (241).

Member-at-Large: Carolyn Dusenbury, Head of Reference Service, 110 Hayden Library, Arizona State University, Tempe, AZ 85287 (335); Jacquelyn M. Morris, Associate Director of Libraries, University of the Pacific, Stockton, CA 95211 (306).

\section{College Libraries Section}

Vice-Chair/Chair-Elect: JeAn Clarridge Pelletière, Director, Union College Libraries, Schenectady, NY 12308 (256); Pamela Snelson, Head, Periodicals Department, Drew University Library, Madison, NJ 07940 (188).

Secretary: JANET SHEETs, Reference Librarian, Baylor University, P.O. Box 6307, Waco, TX 76798 (241); Frances Cable, Associate Librarian, Reference Department, Pennsylvania State University, University Park, PA 16802 (185). 


\section{Community and Junior College Libraries Section}

Vice-Chair/Chair-Elect: JAMES F. MCCoY, Director of Learning Resources, Hudson Valley Community College, 80 Vandenburgh Ave., Troy, NY 12180 (103); Kay M. Stansbery, Director of Technical Services, Tarrant County Junior College, 828 Harwood Rd., Hurst, TX 76053 (75).

Secretary: IlONa G. Franck, Head Librarian, Jefferson Community College/Southwest, 1000 Community College Drive, Louisville, KY 40272 (90); Joseph Rine, Head Librarian, Minneapolis Community College Library, 1501 Hennepin, Minneapolis, MN 55403 (74).

\section{Education and Behavioral Sciences Section}

Vice-Chair/Chair-Elect: AdELE S. DENDy, Head, Education Library, Indiana University Library, 3rd and Jordan St., Bloomington, IN 47405 (138); Charles Thurston, Education Reference Librarian, John Peace Library, University of Texas at San Antonio, San Antonio, TX 78285 (92).

\section{Law and Political Science Section}

Vice-Chair/Chair-Elect: KathlEen GunNing, Assistant Director for Public Services and Collection Development, University of Houston, Houston, TX 77004 (78); Stephen J. Bensman, Social Sciences Bibliographer, Troy H. Middleton Library, Louisiana State University, Baton Rouge, LA 70803 (53).

Member-at-Large: NATALIE Schatz, Librarian, Edward Ginn Library, Fletcher School of Law and Diplomacy, Tufts University, Medford, MA 02155 (76); Fred Blum, Reference Librarian, Eastern Michigan University, Ypsilanti, MI 48197 (56).

\section{Rare Books and Manuscripts Section}

Vice-Chair/Chair-Elect: AnNa Lou Ashby, Associate Curator of Printed Books, Pierpont Morgan Library, 29 E. 36th St., New York, NY 10016 (219); Marie E. Korey, Rare Book Librarian, Free Library of Philadelphia, Logan Square, Philadelphia, PA 19103 (158).

Member-at-Large: RoBErT NikiRK, Librarian, The Grolier Club, 47 E. 60th St., New York, NY 10022 (234); R. Russell Maylone, Curator, Special Collections Department, Northwestern University Library, Evanston, IL 60201 (142).

\section{Science and Technology Section}

Vice-Chair/Chair-Elect: EleANor Mathews, Reference Librarian, Iowa State University Library, Ames, IA 50011 (138); John W. Beecher, Head of Public Services, University of Minnesota,
St. Paul Campus Library, 1984 Buford Ave., St. Paul, MN 55108 (125).

Secretary: JAMES E. Bobick, Head of Collection Development, Temple University, Paley Library, Room 211, Philadelphia, PA 19122 (146); Marie Dvorzak, Head, Winchell Library of Geology, University of Minnesota, 204 Pillsbury Hall, Minneapolis, MN 54455 (120).

\section{Slavic and East European Section}

Vice-Chair/Chair-Elect: WoJCIECH ZaLEWSKI, Curator for Russian and East European Collections, Stanford University Libraries, Stanford, CA 94305 (26); Nadia Zilper, Slavic and East European Resources Bibliographer, University of North Carolina, Chapel Hill, NC 27514 (15).

Secretary (three-year term): LEON FERDER, Slavic Bibliographer, University of California, Los Angeles, CA 90024 (28); Robert Fitzgerald, Slavic Cataloger, Northwestern University Library, 1935 Sheridan Rd., Evanston, IL 60201 (13).

Member-at-Large: Edward Kasinec, Chief, Slavonic Division, Room 217, New York Public Library, 5th Ave. and 42d St., New York, NY 10018 (24); Natalia Bezugloff, Head, Foreign Literature Department, Cleveland Public Library, 325 Superior Ave., Cleveland, $\mathrm{OH} 44114$ (17).

\section{University Libraries Section}

Vice-Chair/Chair-Elect: Shelley E. Phipps, Head Librarian, Science-Engineering Library, University of Arizona, Tucson, AZ 85721 (847); Patricia L. Bril, Chair, Readers Services Department, California State University, P.O. Box 4150, Fullerton, CA 92634 (570).

\section{Western European Specialists Section}

Vice-Chair/Chair-Elect: JAMEs CAMPBELL, North Europe Bibliographer, Alderman Library, University of Virginia, Charlottesville, VA 22901 (65); John B. Dillon, Humanities Bibliographer, Glenn G. Bartle Library, SUNY-Binghamton, Binghamton, NY 13901 (53).

Secretary: C. Roger Davis, Bibliographer, Smith College Library, Northampton, MA 01063 (82); Richard Bruce Warr, Humanities/History Bibliographer, Alexander Library, Rutgers-The State University, New Brunswick, NJ 08903 (34).

Member-at-Large: MarianN Tiblin, Bibliographer, Scandinavian Area Studies, Wilson Library, University of Minnesota, 309 19th Ave. S., Minneapolis, MN 55455 (60); Assunta S. Pisani, Coordinator of Collection Development, Widener Library, Harvard University, Cambridge, MA 02138 (54).

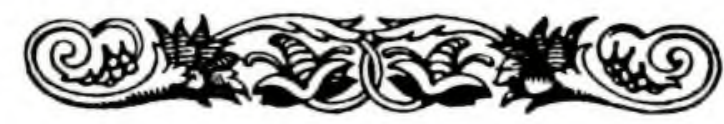

